\title{
PENINGKATAN HASIL BELAJAR MATEMATIKA DENGAN IKODAPAT PADA SISWA SLB TUNAGRAHITA
}

\author{
Sudiryo \\ SLB Manunggal Slawi \\ Emailssudiryo@gmail.com
}

\begin{abstract}
Abstrak
Tujuan umum penelitian ini meningkatkan hasil belajar matematika. Upaya peningkatan hasil belajar matematika pada penelitian ini melalui model pembelajaran kooperatif teknik Ikodapat (isi kotak pada tempatnya). Teknik Ikodapat pada operasi perkalian dengan menyediakan kotak untuk menuliskan hasilnya. Bagi siswa SLB Manunggal Slawi pelajaran matematika masih dianggap sebagai pelajaran yang amat sulit untuk dipelajari, sehingga hasil yang diperoleh siswa masih sangat jauh dari yang diharapkan. Sebagai gambaran dari hasil ulangan harian matematika siswa kelas VII Tunagrahita SLB Manunggal Slawi materi sebelumnya, siswa yang memperolah nilai $\geq 67$ (sesuai dengan Standar Ketuntasan Belajar Minimal) belum ada. Oleh sebab itu harus diupayakan kiat untuk meminimalkan kesulitan-kesulitan belajar matematika yang dihadapi siswa.

Kegiatan penelitian ini menggunakan metode penelitian tindakan kelas yangterdiri dari dua siklus. Langkah-langkah dalam setiap siklus terdiri dari perencanaan (planning). pelaksanaan tindakan (acting), pengamatan (observing), dan refleksi (reflecting). Sebelum diberi tindakan hasil belajar siswa pada ulangan harian matematika materi perkalian bilangan, nilai rata-ratanya 40. Peran aktif siswa dalam pembelajaran masih relatif rendah. Pada siklus I guru menggunakan teknik ikodapat, nilai rata-rata hasil belajar matematika meningkat sebesar 67. Peran aktif siswa dalam pembelajaran meningkat ditandai dengan diskusi kelompok yang lebih hidup. Pada siklus II guru melanjutkan teknik ikodapat untuk perkalian bersusun 2 angka. Nilai rata-rata hasil belajar matematika pada siklus II sebesar 74. Peran aktif siswa selama dua pertemuan pada siklus II meningkat secara signifikan. Hal ini ditandai dengan semakin hidup pelaksanaan diskusi karena antar kelompok mempresentasikan hasil diskusi dan ditanggapi kelompok lain.
\end{abstract}

Kata Kunci: teknik Ikodapat, keaktifan belajar, hasil belajar

\section{PENDAHULUAN}

Bagi siswa SLB Manunggal Slawi pelajaran matematika masih dianggap sebagai pelajaran yang amat sulit untuk dipelajari, sehingga hasil yang diperoleh siswa masih sangat jauh dari yang diharapkan. Sebagai gambaran dari hasil ulangan harian matematika siswa kelas VII Tunagrahita SLB Manunggal Slawi materi perkalian biasa (mendatar), siswa belum ada yang memperolah nilai $\geq 67$ (sesuai dengan standar ketuntasan belajar minimal). Oleh sebab itu harus diupayakan kiat untuk meminimalkan kesulitan-kesulitan belajar matematika yang dihadapi siswa.

Peneliti mengambil materi perkalian bilangan bersusun, karena kebanyakan siswa selama penelitimenyampaikanmateriini banyak mengalami kesulitan dan hasil yang kurang membanggakan.
Padahal banyak soal yang berhubungan dengan materi perkalian pada kehidupan sehari-hari, misalnya menghitung barang yang sama dengan jumlah cukup banyak. Untuk mengantisipasi permasalahan di atas, perlu diupayakan suatu pembelajaran guna meminimalkan kesulitan belajar siswa.

Pembelajaran dengan model Kooperatif yang diterapkan beraneka ragam. Adapun usaha yang akan dilakukan untuk mengupayakan belajar bermakna pada mata pelajaran matematika materi perkalian bilangan bersusun dengan model pembelajaran kooperatif guru memandang perlu menggunakan teknik isi kotak pada tempatnya (Ikodapat).

Pada tahap awal sebelum guru menggunakan pendekatan model pembelajaran kooperatif dengan 
teknik Ikodapat hasil belajar matematika siswa kelas VII Tunagrahita SLB Manunggal Slawi masih rendah.

Dari latar belakang masalah, bahwa di kelas VII Tunagrahita Semester II Tahun Pelajaran 2016/2017 SLB Manunggal Slawi Kabupaten Tegal, dapat diidentifikasi sebab-sebab timbulnya masalah sebagai berikut: penggunaan metode pembelajaran yang konvensional, guru hanya mengejar penyelesaian materi sesuai dengan jadwal dalam rencana pelaksanaan pembelajaran tanpa memberikan kesempatan siswa benarbenar memahami materi tersebut, guru belum menggunakan media pembelajaran yang tepat untuk membantu siswa memahami konsep-konsep yang abstrak, serta motivasi belajar, perhatian, dan kemandirian siswa masih rendah

Hasil penelitian ini diharapkan bermanfaat bagi siswa, guru, dan sekolah. Siswa mendapatkan pengalaman belajar yang bermakna yang dapat dipergunakan untuk menyelesaikan permasalahan yang dihadapinya. Hal ini karena suasana pembelajaran menyenangkan, motivasi belajar siswa meningkat, sehingga pada akhirnya akan meningkatkan hasil belajar siswa, khususnya hasil belajar matematika materi Perkalian Bersusun. Guru bertambah wawasan dan informasi untuk memilih bentuk-bentuk pendekatan pembelajaran yang menarik dan menyenangkan bagi siswa. Bagi sekolah hasil penelitian ini dapat dijadikan acuan dalam membuat kebijakan tentang peningkatan kualitas pembelajaran di SLB Manunggal Slawi, melalui pelatihan bagi guru tentang metode pembelajaran dan media pembelajaran.

Hasil belajar menunjukkan kepada prestasi belajar, sedangkan prestasi belajar itu merupakan indikator adanya derajat perubahan tingkah laku siswa. (Hamalik, 2001: 159). Hasil belajar adalah hasil dari suatu interaksi tindak belajar mengajar dan biasanya ditunjukkan dengan nilai tes yang diberikan guru (Nasution, 2006: 36). Hasil belajar adalah hasil yang ditunjukkan dari suatu interaksi tindak belajar dan biasanya ditunjukkan dengan nilai tes yang diberikan guru (Dimyati dan Mudjiono, 2002: 36). Belajar difokuskan pada tercapainya daya pikir dan tindakan yang berkualitas untuk memecahkan masalah-masalah yang kini dan nanti dihadapi siswa (Muhibbinsyah, 2014: 90)

Dari uraian di atas dapat disimpulkan bahwa hasil belajar merupakan hasil yang diperoleh siswa setelah terjadinya proses pembelajaran yang ditunjukkan dengan nilai tes yang diberikan oleh guru setiap selesai memberikan materi pelajaran pada satu pokok bahasan.

Dalam penelitian tindakan kelas ini, yang dimaksud hasil belajar siswa adalah hasil nilai ulangan harian yang diperoleh siswa pada mata pelajaran matematika materi perkalian bersusun.

Menurut WJS Purwodarminto (2011 : 17) Secara harfiah keaktifan berasal dari kata aktif yang berarti sibuk, giat. Aktif mendapat awalan ke- dan -an, sehingga menjadi keaktifan yang mempunyai arti kegiatan atau kesibukan. Jadi, keaktifan belajar adalah kegiatan atau kesibukan siswa dalam kegiatan belajar mengajar di sekolah maupun di luar sekolah yang menunjang keberhasilan belajar siswa.

Faktor yang mempengaruhi keaktifan belajar siswa diklasifikasikan menjadi dua macam, yakni faktor intern (faktor dari dalam diri manusia itu sendiri) yang meliputi faktor fisiologis dan psikologi dan faktor ektern (faktor dari luar manusia) yang meliputi faktor sosial dan non sosial. (Abu Ahmadi \& Widodo Supriyono,2008: 78)

Kemendikbud (2014: 144) perkalian bersusun kebawah yang digunakan dalam pembelajaran, menyatakan bahwa penyelesaian operasi perkalian bilangan asli dengan teknik penyusunan ke bawah nilai satuan pada bilangan bawah dikalikan dengan nilai satuan bilangan diatas, lalu hasil perkalian tulis nilai satuan sedangkan nilai puluhan disimpan, nilai satuan bilangan bawah dikalikan dengan nilai puluhan bilangan atas dan ditambah nilai simpanan perkalian pertama.

\section{Contoh}

35

$\underline{3} \times \quad 5 \times 3=15$ tulis 5 simpan $1 \frac{3}{5} \mathrm{x}$ simpan 1

$3 \times 3=9$ ditambah 1 hasilnya $10 \frac{3}{105} \times$ 
Pembelajaran harus berprinsip pada pemberdayaan semua potensi siswa untuk meningkatkan pemahaman fakta, konsep, dan prinsip dalam kajian ilmu yang dipelajarinya. Pembelajaran harus berpusat pada siswa agar kreatif, menyenangkan dan menantang dan belajar melalui perbuatan (Masnur, Muslich, 2008:71).

Guru selaku peneliti melaksanakan kegiatan belajar mengajar agar siswa kreatif, pembelajaran menyenangkan dan menantang serta siswa belajar melalui perbuatan. Dengan dasar itu peneliti menggunakan teknik Ikodapat singkatan dari I = Isi, ko = kotak, da = pada, pat = tempatnya . Teknik ini merupakan ide peneliti sendiri. Peneliti menggunakan teknik Ikodapat pada perkalian bersusun sederhana.

Langkah teknik Ikodapat pada perkalian bersusun perhatikan contoh berikut :

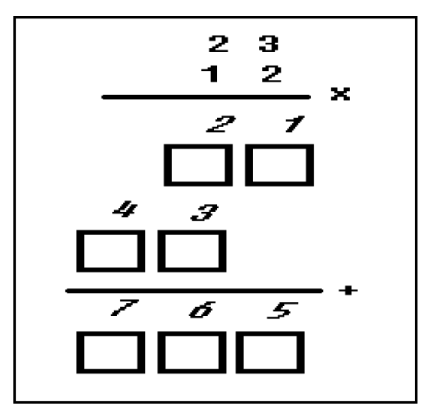

Langkah-langkah teknik Ikodapat sebagai berikut:

1. Isi kotak 1 dari hasil perkalian 3 dengan 2

2. Isi kotak 2 dari hasil perkalian 2 dengan 2

3. Isi kotak 3 dari hasil perkalian 3 dengan 1

4. Isi kotak 4 dari hasil perkalian 2 dengan 1

5. Isi kotak 5 seperti hasil kotak 1

6. Isi kotak 6 merupakan jumlah dari kotak 2 dan kotak 3

7. Isi kotak 7 seperti hasil kotak 4

8. Hasil perkalian dibaca mulai dari kotak 7, kotak 6 , dan kotak 5

Kelebihan teknik Ikodapat meningkatkan keaktifan siswa dalam pembelajaran sehingga pembelajaran berpusat pada siswa, peran guru hanya bertindak sebagai fasilitator dan membimbing kegiatan siswa. Dilihat dari sisi guru itu sendiri terlihat adanya suatu proses optimalisasi tugas dengan memberikan pembelajaran yang menarik, kreatif dan bermakna bagi pencapaian hasil belajar siswa.

Kekurangan teknik Ikodapat diantaranya pembelajaran matematika belum optimal jika sebagian siswa kurang aktif. Partisipasi pada diskusi kelompok untuk menyelesaikan masalah jika didominasi oleh siswa tertentu, maka akan terlihat banyak siswa yang pasip.

Untuk memfokuskan penelitian, maka masalah dibatasi pada penggunaan model pembelajaran kooperatif menggunakan teknik Ikodapat untuk meningkatkan hasil belajar matematika materi Perkalian Bersusun pada siswa kelas VII Tunagrahita SLB Manunggal Slawi semester II tahun pelajaran 2016/2017. Peningkatan keaktifan siswa sangat berpengaruh pada peningkatan hasil belajar matematika.

Masalah yang diangkat dari penelitian ini adalah 1) Apakah penggunaan model pembelajaran kooperatif teknik Ikodapat, dapat meningkatkan hasil belajar matematika?, 2) Apakah penggunaan model pembelajaran kooperatif teknik Ikodapat, dapat meningkatkan keaktifan belajar matematika?, 3) Bagaimana proses pembelajaran dengan penggunaan model pembelajaran kooperatif teknik Ikodapat, dapat meningkatkan keaktifan dan hasil belajar matematika materi Perkalian Bersusun pada siswa kelas VII Tunagrahita SLB Manunggal Slawi semester II tahun pelajaran 2016/2017?

\section{METODE PENELITIAN}

Pembelajaran dengan teknik Ikodapat menggunakan teknik penelitian tindakan kelas yang dilakukan peneliti terdiri dari 2 siklus. Siklus I berisi paket I meliputi Perkalian bersusun sederhana I. Siklus II berisi paket II meliputi Perkalian bersusun sederhana II.

Penelitian ini dilakukan dengan menggunakan penelitian tindakan kelas (PTK) yang terdiri dari dua siklus. Langkah setiap siklus terdiri dari perencanaan (planning), pelaksanaan tindakan (acting), pengamatan (observing), dan refleksi (reflecting). 
Langkah pada siklus I adalah perencanaan (Planning) meliputi penyusunan Rencana Pembelajaran (RP), penyusunan rencana pembentukan kelompok, menyiapkan instrumen observasi. Pelaksanaan tindakan (acting). dilaksanakan sesuai Rencana Pembelajaran (RP) meliputi: memberikan penjelasan mengenai teknik belajar menggunakan model pembelajaran kooperatif teknik Ikodapat dan apa yang harus dilaksanakan siswa, membagi siswa menjadi beberapa kelompok terdiri dari 3 sampai 4 orang siswa, siswa belajar secara kelompok dengan mengikuti tahapan pembelajaran teknik Ikodapat, melakukan pemantauan dan bimbingan. Pengamatan (Observing) dengan menggunakan instrumen observasi yang telah disediakan, selama pelaksanaan kegiatan dilakukan pengamatan melalui keterlibatan atau keaktifan siswa dalam proses pembelajaran.
Refleksi (Reflecting) dilakukan untuk mengetahui sejauh mana efektivitas pelaksanaan tindakan pada siklus I, kekurangan dan kelebihan yang timbul pada siklus I digunakan sebagai bahan pertimbangan pelaksanaan siklus II.

Langkah-langkah pada siklus II pada prinsipnya sama dengan siklus I, hanya pada siklus II hasil kerja kelompok dipresentasikan di depan kelas oleh ketua atau anggota kelompok yang ditunjuk.

Mencermati hal tersebut diharapkan dengan menggunakan model pembelajaran kooperatifteknik Ikodapat hasil belajar matematika siswa kelas VII Tunagrahita SLB Manungal Slawi semester II tahun pelajaran 2016/2017 meningkat.

Berdasarkan uraian di atas, kiranya dapat disusun kerangka berpikir penelitian tindakan kelas sebagaimana ditunjukkan pada grafik berikut ini :

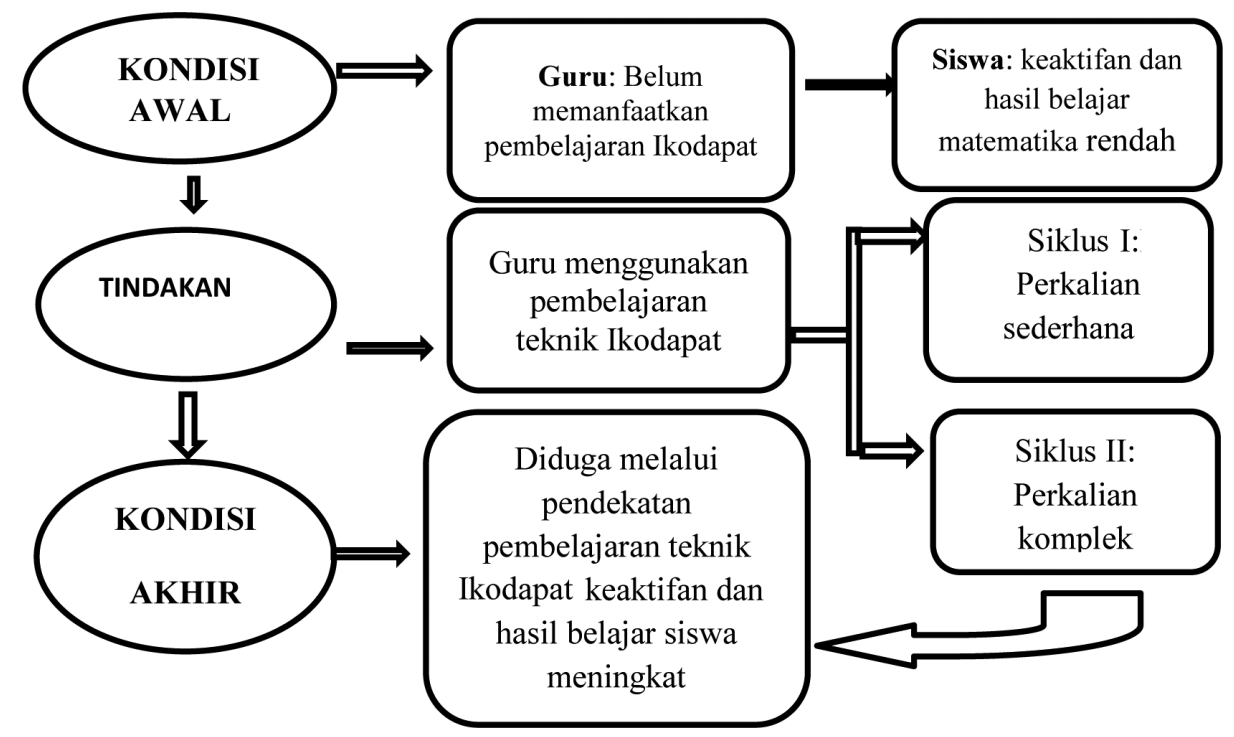

Grafik 1. Kegiatan pada PTK

Penelitian tindakan kelas ini mengambil objek tindakan penelitian berupa hasil belajar Matematika materi Perkalian Bersusun pada siswa kelas VII Tunagrahita SLB Manunggal Slawi Tahun Pelajaran 2016/2017. Penerapan model pembelajran kooperatif teknik Ikodapat peneliti akan berupaya meningkatkan keaktifan dan hasil belajar matematika pada siswa kelas VII Tunagrahita SLB Manunggal Slawi Tahun Pelajaran 2016/2017. Peningkatan hasil belajar berupa ketuntasan belajar perorangan ditetapkan jika siswa memperoleh nilai hasil belejar sama atau di atas nilai kriteria ketuntasan minimal Matematika sebesar $67(\mathrm{KKM}=67)$, sedangkan ketuntasan belajar klasikal ditetapkan jika jumlah siswa yang telah tuntas belajar perorangan dalam satu kelas terjadi peningkatan.

Tempat penelitian ini adalah SLB Manunggal Slawi, Jalan Ahmad Yani No.86 Slawi Kabupaten Tegal, Propinsi Jawa Tengah. Agar penelitian ini tidak mengganggu proses belajar 
mengajar disusun jadwal penelitian. Penelitian dilakukan selama 2 bulan yaitu Maret sampai dengan April 2017. Untuk mengupayakan adanya keterpaduan dengan jadwal penelitian, kegiatan disesuaikan dengan jadwal pelajaran matematika di kelas VII Tunagrahita .

Subjek penelitian ini adalah siswa kelas VII Tunagrahita SLB Manunggal Slawi semester II Tahun Pelajaran 2016/2017 berjumlah 7 siswa $(\mathrm{L}=2$ dan $\mathrm{P}=5$ )

Penelitian ini menggunakan dua teknik pengumpulan data, yaitu 1) teknik tes digunakan untuk mengukur kemajuan belajar siswa dalam bentuk nilai hasil belajar siswa, 2) teknik Observasi digunakan untuk merekam aktivitas siswa dalam pembelajaran maupun untuk mengetahui kemajuan proses pembelajaran.

Adapun teknik validasi yang digunakan dalam penelitian tindakan kelas ini antara lain : model Analisis Interaktif Miles \& Huberman

Dalam penelitian kualitatif memungkinkan dilakukan analisis data pada waktu peneliti berada di lapangan maupun setelah kembali dari lapanganbaru dilakukan analisis. Pada penelitian ini analisis data telah dilaksanakan bersamaan dengan proses pengumpulan data. Alur analisis mengikuti model analisis interaktif sebagaimana diungkapkan Miles. Miles dan Huberman (2014:23) menyatakan bahwa teknis yang digunakan dalam menganalisis data dapat divisualisasikan sebagai berikut:

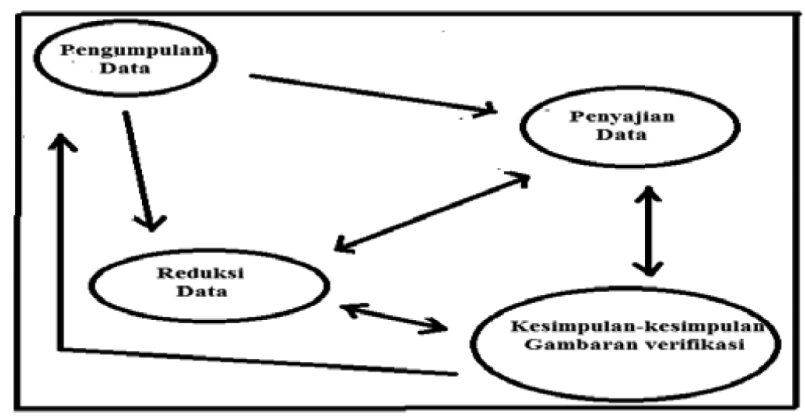

Grafik 2. Analisis Interaktif Miles \& Huberman

Teknik Analisis Komparatif adalah teknik yang digunakan untuk membandingkan kejadiankejadian yang terjadi pada saat peneliti menganalisa kejadian tersebut dan dilakukan secara terus menerus sepanjang penelitian dilakukan.

Hasil belajar yang diukur dengan instrumen tes, hasilnya dianalisis untuk diketahui jumlah nilai masing-masing siswa, nilai tertinggi, nilai terendah, nilai rata-rata dan ketuntasan belajar klasikal. Nilai matematika dianalisis menggunakan deskripsi komparatif. Deskripsi komparatif yaitu membandingkan data awal tes antar siklus dengan indikator kinerja yang telah ditetapkan sebelumnya.

Hasil observasi terhadap keaktifan siswa dalam pembelajaran dengan menggunakan pembelajaran kooperatif teknik Ikodapat diukur dengan menggunakan lembar observasi. Hasil observasi dianalisis untuk diketahui jumlah skor perolehan semua indikator observasi. Tiga kriteria keaktifan siswa dalam pembelajaran pada penelitian ini ditunjukan dalam tabel berikut :

Tabel 1. Kriteria Keaktifan siswa

\begin{tabular}{|c|c|c|}
\hline No & Persentase Perolehan & Kriteria Keaktifan Siswa \\
\hline 1 & $0 \%-33,3 \%$ & Tidak Aktif \\
\hline 2 & $33,4 \%-66,6 \%$ & Cukup Aktif \\
\hline 3 & $66,7 \%-100 \%$ & Sangat Aktif \\
\hline
\end{tabular}

Hasil belajar siswa pada penelitian ini mencakup ketuntasan belajar perorangan dan klasikal. Indikator capaian pada ketuntasan belajar perorangan ditetapkan jika siswa memperoleh nilai hasil belajar lebih dari atau sama dengan nilai Kriteria Ketuntasan Minimal mapel Matematika sebesar $67(\mathrm{KKM}=67)$, sedangkan ketuntasan belajar klasikal ditetapkan jika jumlah siswa yang telah tuntas belajar perorangan dalam satu kelas terjadi peningkatan. Keaktifan siswa dalam pembelajaran, ditetapkan indikator capaiannya jika keaktifan siswa dalam pembelajaran telah mencapai sama atau lebih dari $67 \%$ dengan kriteria sangat aktif.

\section{HASIL DAN PEMBAHASAN}

Hasil observasi keaktifan siswa dalam pembelajaran kooperatif menggunakan Teknik 
Ikodapat yang peneliti lakukan untuk mata pelajaran matematika materi Perkalian Bersusun pada siswa kelas VII Tunagrahita SLB Manunggal Slawi
Semester II Tahun pelajaran 2016/2017ditunjukan pada tabel dan grafik berikut.

Tabel 2. Hasil Observasi Keaktifan Siswa Antar Siklus

\begin{tabular}{|c|l|c|c|c|c|c|c|}
\hline \multirow{2}{*}{ No } & \multicolumn{1}{|c|}{ Indikator Observasi } & \multicolumn{2}{c|}{ Kondisi awal } & \multicolumn{2}{c|}{ Siklus I } & \multicolumn{2}{c|}{ Siklus II } \\
\cline { 3 - 8 } & & $\begin{array}{c}\text { Jml } \\
\text { Siswa }\end{array}$ & $\%$ & $\begin{array}{c}\text { Jml } \\
\text { siswa }\end{array}$ & $\%$ & $\begin{array}{c}\text { Jml } \\
\text { siswa }\end{array}$ & $\%$ \\
\hline 1 & Semangat mengikuti pembelajaran matematika & 3 & $43 \%$ & 4 & $57 \%$ & 6 & $85 \%$ \\
\hline 2 & $\begin{array}{l}\text { Partisipasi pada diskusi kelompok untuk } \\
\text { menyelesaikan masalah }\end{array}$ & 2 & $29 \%$ & 3 & $43 \%$ & 5 & $71 \%$ \\
\hline 3 & Memberikan pertanyaan kepada kelompok lain & 1 & $14 \%$ & 2 & $29 \%$ & 3 & $43 \%$ \\
\hline 4 & Menanggapi hasil kerja dari kelompok lain & 1 & $14 \%$ & 2 & $29 \%$ & 3 & $43 \%$ \\
\hline & Rata-rata & 2 & $29 \%$ & 3 & $43 \%$ & 5 & $71 \%$ \\
\hline
\end{tabular}

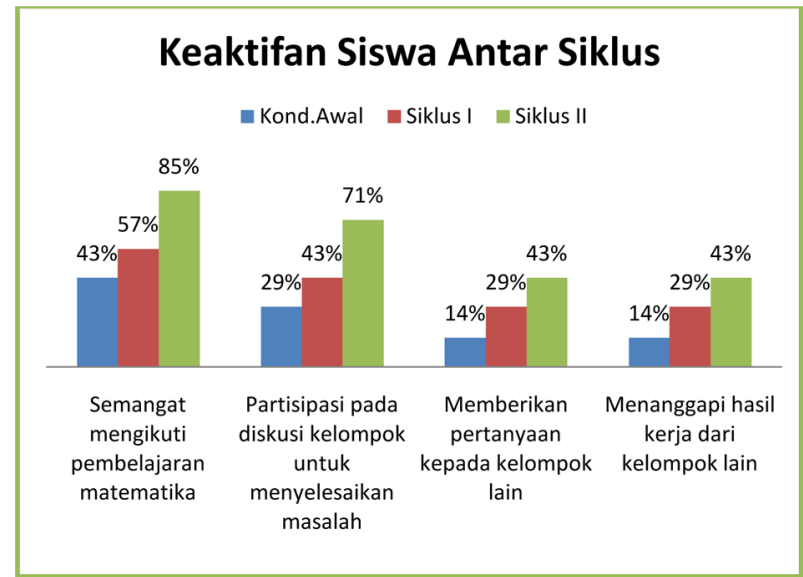

Grafik 3. Hasil Observasi Keaktiafan Siswa Antar Siklus

Analisis lembar observasi terhadap aktivitas siswa pembelajaran kondisi awal diperoleh data bahwa semangat mengikuti pembelajaran matematika $43 \%$, partisipasi pada diskusi kelompok untuk menyelesaikan masalah 29\%, memberikan pertanyaan kepada kelompok lain $14 \%$, menanggapi hasil kerja dari kelompok lain14\%, dan rata-rata sebesar 29\% dengan kriteria tidak aktif.

Analisis lembar observasi terhadap keaktifan siswa pada pembelajaran siklus I diketahui bahwa semangat mengikuti pembelajaran matematika $57 \%$, partisipasi pada diskusi kelompok untuk menyelesaikan masalah $43 \%$, memberikan pertanyaan kepada kelompok lain 29\%, menanggapi hasil kerja dari kelompok lain $29 \%$, dan rata-rata keaktifan siswa pada pembelajaran siklus I sebesar 43\% dengan kriteria cukup aktif

Analisis lembar observasi terhadap aktivitas siswa pada pembelajaran siklus II diketahui bahwa semangat mengikuti pembelajaran matematika $85 \%$, partisipasi pada diskusi kelompok untuk menyelesaikan masalah $71 \%$, memberikan pertanyaan kepada kelompok lain sebanyak 43\%, menanggapi hasil kerja dari kelompok lain 43\%, dan rata-rata keaktifan siswa pada pembelajaran siklus II sebesar $71 \%$ dengan kriteria sangat aktif.

Uraian hasil observasi keaktifan siswa dalam pembelajaran kooperatif menggunakan Teknik Ikodapat yang peneliti lakukan untuk mata pelajaran matematika materi Perkalian Bersusun pada siswa kelas VII Tunagrahita SLB Manunggal Slawi Semester II Tahun pelajaran 2016/2017 menunjukkan kondisi awal 29\% siswa dengan kriteria tidak aktif, siklus I mencapai 43\% siswa dengan kriteria cukup aktif, dan pada siklus II mencapai $71 \%$ siswa dengan kriteria sangat aktif. Hal tersebut menunjukkan bahwa penggunaaan teknik Ikodapat keaktihan siswa mengalami kenaikan yang signifikan

Nilai hasil belajar siswa diukur dengan tes hasil belajar (ulangan harian) siswa yang dilakukan pada setiap akhir kegiatan pembelajaran. Perhatikan tabel dan grafik berikut 
Tabel 3. Analisis Hasil Tes Antar siklus

\begin{tabular}{|c|l|c|c|c|}
\hline No & \multicolumn{1}{|c|}{ Indikator } & Kondisi Awal & Siklus I & Siklus II \\
\hline 1 & Jumlah siswa & 7 siswa & 7 siswa & 7 siswa \\
\hline 2 & Jumlah Nilai & 280 & 470 & 520 \\
\hline 3 & Nilai Rata-rata & 40 & 67 & 74 \\
\hline 4 & Nilai tertinggi & 50 & 80 & 90 \\
\hline 5 & Nilai Terendah & 30 & 50 & 60 \\
\hline 6 & Tuntas Belajar & 0 siswa $(0 \%)$ & 4 siswa $(57 \%)$ & 5 siswa (71 \%) \\
\hline 7 & Belum Tuntas Belajar & 7 siswa $(100 \%)$ & 3 siswa $(43 \%)$ & 2 siswa $(29 \%)$ \\
\hline
\end{tabular}

\section{Ketuntasan Hasil Tes Antar Siklus}

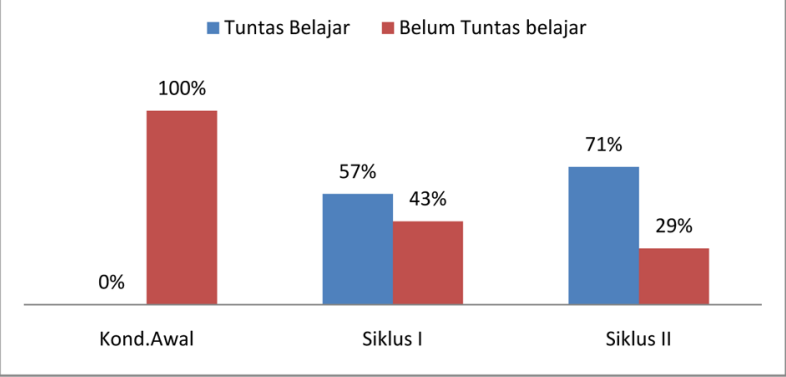

Grafik 4. Ketuntasan Hasil Tes Antar Siklus

Analisis hasil ulangan harian materi Perkalian Bersusun pada siswa kelas VII Tunagrahita SLB Manunggal Slawi semester II tahun pelajaran 2016/2017 pada kondisi awal sebagai berikut: nilai rata-rata 40 , nilai tertinggi 50 , nilai terendah 30 , tuntas belajar $0 \%$ dan belum tuntas belajar $100 \%$.

Analisis hasil ulangan harian matematika materi Perkalian Bersusun pada siswa kelas VII Tunagrahita SLB Manunggal Slawi semester II tahun pelajaran 2016/2017pada siklus I sebagai berikut: nilai rata-rata 67 , nilai tertinggi 80 , nilai terendah 50, memperoleh nilai $\geq 67$ (tuntas belajar sesuai KKM 67) adalah $57 \%$ dan belum tuntas belajar $43 \%$.

Analisis hasil ulangan harian matematika materi Perkalian Bersusun II pada siswa kelas VII Tunagrahita SLB Manunggal Slawi semester II tahun pelajaran 2016/2017 siklus II sebagai berikut: nilai rata-rata 74 , nilai tertinggi 90 , nilai terendah 60 , memperoleh nilai $\geq 67$ (tuntas belajar sesuai KKM 67) adalah $71 \%$ dan belum tuntas belajar $29 \%$.

Nilai hasil belajar siswa diukur dengan tes hasil belajar siswa yang dilakukan pada setiap akhir kegiatan pembelajaran. Pada setiap indikator ratarata mengalami kenaikan. Siswa yang tuntas belajar pada kondisi awal $0 \%$, siklus I mencapai 57\%, dan siklus II mencapai $71 \%$. Siswa belum tuntas belajar pada kondisi awal 100\%, siklus I turun menjadi $43 \%$, dan siklus II turun menjadi 29\%. Dari data tersebut menunjukkan bahwa terjadi peningkatan yang signifikan, jika dibandingkan kondisi awal dengan siklus I terjadi peningkatan $57 \%$,siklus I dan siklus II terjadi peningkatan $14 \%$. Sebaliknya siswa belum tuntas belajar mengalami penurunan, jika dibandingkan kondisi awal dengan siklus I penurunan sebesar $57 \%$, sedangkan siklus I dan siklus II terjadi penurunan $14 \%$.

Berdasarkan semua hasil penelitian sebagaimana diuraikan di atas, dapat disimpulkan bahwa proses pembelajaran dengan adanya perlakuan penggunaan teknik Ikodapat dapat meningkatkan keaktifan siswa. Peningkatan keaktifan belajar siswa berpengaruh terhadap peningkatan hasil belajar siswa. Dengan demikian tindakan yang dilakukan dalam penelitian tindakan kelas ini dapat dikatakan bahwa penggunaan teknik Ikodapat dapat meningkatkan hasil belajar matematika materi perkalian bersusun pada siswa kelas VII Tunagrahita SLB Manunggal Slawi Semester II Tahun Pelajaran 2016/2017.

\section{SIMPULAN}

Keaktifan siswa dalam pembelajaran matematika materi perkalian bersusun karena pengaruh penggunaan model pembelajaran teknik Ikodapat yang menarik dan menyenangkan, Keaktifan siswa tersebut dapat meningkatkan hasil belajar. Hal tersebut dapat diketahui dari nilai tes 
hasil belajar yang telah diukur peneliti yaitu nilai hasil belajar dengan indikator ketuntasan belajar klasikal pada kondisi awal hanya sebesar $0 \%$, pada siklus I menjadi $43 \%$ dan siklus II meningkat menjadi $71 \%$.

Guru diharapkan dapat menggunakan model pembelajaran teknik Ikodapat dalam pembelajaran matematika, mengingat cukup signifikan dampak positif terhadap peningkatan keaktifan dan hasil belajar siswa. Guru dalam menerapkan model pembelajaran kooperatif teknik Ikodapat tetap memperhatikan kesesuaian materi dengan tujuan yang hendak dicapai, karakeristik siswa dan ketersediaan sarana prasarana. Tiga hal penting yangjuga harus diperhatikan antara lain pengelompokan siswa, semangat kerjasama antar siswa dan penataan atau pengelolaan kelas untuk kerja kelompok.

\section{DAFTAR PUSTAKA}

Ahmadi, Abu \& Widodo Supriyono. (2008). Psikologi Belajar. Jakarta: Rineka Cipta.

Dimyati dan Mudjiono. (2002). Belajar dan Pembelajaran. Jakarta: Rineka Cipta.

Hamalik, Oemar. (2001). Proses Belajar Mengajar. Jakarta: Bumi Aksara.

Kemendikbud (2014), Ringan Sama Dijinjing Berat Sama Dipikul, SMPLB Tunagrahita Kelas VII Tema 2 Buku Tematik Terpadu Kurikulum Pendidikan Khusus 2013

Masnur, Muslich. (2008). KTSP Pembelajaran Berbasis Kompetensi dan Kontekstual. Jakarta: Bumi Aksara.

Miles,M.B, Huberman, A.M, dan Saldana, J. (2014). Qualitative Data Analysis, A Methods Sourcebook, Edition 3. Terjemahan Tjetjep Rohindi Rohidi. Jakarta: UI-Press.

Muhibbinsyah. 2014, Psikologi Pendidikan Dengan Pendekatan Baru. PT Remaja Rosdakarya. Bandung

Nasution. 2006. Pendekatan Dalam Proses Belajar dan Mengajar. Bumi Aksara. Jakarta

WJS Purwodarminto. 2011. Kamus Umum Bahasa Indonesia Edisi Ketiga, Balai Pustaka. Jakarta 